\title{
Kleinheubach-U.R.S.I.: 48 years home for the German-Austrian Beacon Satellite Community (BSC)
}

\author{
G. K. Hartmann \\ CM-Institute (Civilisations Matter) e.V., Reinhardtstr. 47A, 10117 Berlin, Germany \\ Correspondence to: G. K. Hartmann (gkh@cm-germany.org)
}

Received: 28 November 2013 - Revised: 24 February 2014 - Accepted: 3 March 2014 - Published: 11 November 2014

Prof. Dr. Karl Rawer dedicated for his 100th birthday.

\section{Introduction}

The most important milestones in space research and space technology in the last century have been created 1957 by Russia with its Sputnik satellite and by the USA in 1969 with the NASA mission APOLLO 11 and occurred between a "Russian anti-positivism" and an "US romantic pragmatism" (Hartmann, 2011) leading after the AOPLLO paradigm change in 1972 in USA to a growing "enterprise" attitude which got even more pronounced after the end of the cold war 1989 and changed the long term scope of the Beacon Satellite Community (BSC), which started 1965 in Kleinheubach with the investigation of the Upper Atmosphere of the Earth, the Ionosphere (Rawer, 1957, 1986; Hartmann, 1988; Dieminger et al., 1996). The following measurements have been executed: (a) Ionospheric Faraday rotation, (b) Ionospheric Dispersive Doppler Effect and (c) Ionospheric scintillation - the latter was inevitable for an optimization of the satellite communication and navigation technology. (a) and (b) are mainly to determine the Total Electron Content (TEC) of the ionosphere (Davies et al., 1980; Hartmann et al., 1969, 1976, 2000a, b; Leitinger, 1971; Leitinger et al., 1981), the electron content of the plasmasphere and the influence of the ionosphere as a variable temporal and spatial frequency filter for the electromagnetic wave propagation, thus creating the basis for selecting the modern Global Positioning Satellite (GPS) signals. The contemporary German Space research activities have been described by Karl Rawer (1986). Not only the Kleinheubach BSC but also the international COSPAR BSC - the author also speaks on behalf of its sick chairman Reinhart Leitinger - thank K. Rawer for his indispensable, significant support in establishing the interna- tional COSPAR BSC. All BSCs members congratulate him for his 100th anniversary and for staying a "professional" - in the old double sense - scientist, based on his profound Christian belief, which is complementary to the above mentioned US and Russian space research concepts. A more detailed pdf- handout of this text is available from the author. It comprises a more detailed description of the background of the two complementary - Russian and US - space research concepts, a personal dedication for the author by Karl Rawer in his 1986 book, and the author's CV.

\section{The history of the Kleinheubach Beacon Satellite Community (BSC)}

(1) The Sputnik Era (SPE) began 1957 with the launch of the first artificial satellite by the Soviet- union and was in the cold war era a heavy shock for the western world - still when 1965 the Kleinheubach BSC entered the scene, (2) The "Post APOLLO Period" (PAP) beginning in 1972 with the "NASA scientific technological paradigm change", and (3) The PostCold War Era (PCW) beginning in 1989. These phases imply for the mentioned BSC (a) $\sim 10 \%$ of its present lifetime was predominantly for basic research and received significant financial governmental support, which allowed to perform "excellence for the sake of excellence", (b) $35 \%$ was dominated by applied research, and (c) $55 \%$ has been dominated by commercial, economical aspects. This implied that the BSC researchers had more and more had to face a decay of Ionospheric basic research, which used those frequencies that were strongly influenced by the Earth atmosphere (Plasmasphere, Ionosphere and Troposphere), but were disadvantageous (disturbing) for (commercial) satellite communication and navigation systems. There one searched for frequencies that were influenced as little as possible in passing 
the Earth atmosphere. This promoted and supported endeavors in geodesy - separate from BSC activities - and implied that older Ionospheric-BSC results have been "reinvented" in geodesy as K. Rawer stated.

The German Austrian - in its first phase also Finnish (Oksman et al., Sodankylä) - BSC from Kleinheubach was founded together with Reinhart Leitinger, Putz et al. from Graz, Austria. Reinhart eventually became for many years the chairman of the international Beacon Satellite Community (BSC) and contributed yearly to the Kleinheubach BSC meetings - as did Karl Rawer's co-worker Christian Münther - predominantly in the first BSC phase. This is also true for the colleagues from FTZ Darmstadt and for Heinz Kaminski (Sternwarte Bochum). Further German colleagues - also from former East Germany (Jakowski et al., Neustrelitz) especially my colleagues and myself from the Max-PlanckInstitute for Aeroomy (MPAe) at Lindau/Harz, Germany as well as Adolf Ebel (University Cologne/Köln) contributed significantly also to the second phase of these BSC activities. Major contributions to the phase 3) - after 1989 - have only been supplied from Graz and DLR Neustrelitz. Only the latter will supply them - in context with applied research also in the future. A consequence of the complementary war and no-war related research activities.

In the latter phase the discussions of the author with $\mathrm{K}$. Rawer in the yearly Kleinheubach meetings focused less on BSC results but more on the problems that basic science had increasingly to face.

\section{Basic Research and progress between possibilities and limits of digitizing and the uncertainty relation - e.g. complementarity as conceived in quantum physics}

It is not possible to justify Basic research and Space Research only with quick capital return. It is a cultural endeavor and an investment in and for the future. However, regarding Space research and the related Research and Development (R\&D) activities it contributes to today's quality of life in the following way: (a) through necessary and possible global monitoring, (b) through fascination and (national) prestige, through the "example function" of the result from projects executed under the motto "excellence for the sake of excellence". One can read this in Karl Rawer's (1986) book sometimes between the lines. He supported this attitude from the early beginning with his various rocket and satellite experiments. This was discussed several times in Kleinheubach as well as the chances for the investigation the Earth atmosphere - with respect to competition and symbiosis between unmanned and manned Space Research (Bauer, 2003, 2005; Hartmann, 2011).

Progress through science is the motto today! What a difference to the ideas from about 200 years ago, when one began to believe in the progress of science for the first time in Europe! The many discussions which have been led until now have only contributed little to a clarification of this fundamental problem and they will not do as long as we do not know exactly, what we want to understand in detail by the concept "progress". In this context, C. F. von Weizsäcker mentioned: "An unlimited progress, which is only a technical material one and does not contain a greater maturity of consciousness and perception at the same time, can only be disastrous". K. Rawer fully agreed.

\section{Background of the Russian and US Space Research concepts}

1. The US space program enjoyed its most rapid development in the 1960s, culminating in the moon walk in 1969. What was the vision behind it? The US space program was a child of the cold war. The 1961 speech by President John F. Kennedy that set NASA's goals incorporated traditional elements of myth: heroic struggle, personal sacrifice, and the quest for national prominence. Yet the impetus for Kennedy's speech came largely from without. What launched the US space program was the fear of being surpassed by the Soviets, who made a series of bold advances in space travel. The goal of the moon landing was for the United States an attempt not to be overtaken by the Soviet developments in manned space exploration. Few US Americans know about the vision of their Russian competitors in space exploration. The space research program of the USA after APOLLO can be characterised by commercialisation, respectively "enterprise". This brings it always closer to an everyday subject and thus NASA's continuous budget cuts are understandable. Since a trip to the "inner human space" by means of virtual reality (VR) in the cyberspace is a lot cheaper and also easier than a trip to the outer space, private and public support might further decrease for the latter if we stick to the old paths or cannot make (outer) space again more attractive. Is the European (science) policy capable and ready to meet this challenge and to find a new "in- between" for Space research between Russia and the USA?

2. The early Russian space research pioneers were strongly influenced by Nicolai Fedorovich Fedorov (1828-1903) who gave also a powerful inspiration to Soloviev, Dostoevsky and Tolstoy.

He envisioned the conquest of nature as an act of altruism. But being generous to future generations can be less than purely altruistic, for they can return the favor by acclaim of our deeds. We must regulate the forces of nature, he believed, so altruistically that we serve those who cannot possibly return our favors: we must conquer nature in order to resurrect our ancestors, the ultimate act of altruism. Fedorov's strategy was to channel science and technology towards the reunion 
of all humanity - different from Karl Rawer's Christian attitude.

Many technical people today also take enterprise to be the proper name in a science fiction myth, that of the starship Enterprise in "Star Trek", the popular science fiction television series about twenty-first-century space travelers. For hundreds of technicians, the space program flies on the imaginative wings of Gene Roddenberry's brainchild, born on 8 September 1966, when the TV show was first aired. But Roddenberg was not Fedorov. The sage of Pasadena created no unifying vision to direct humanity "where no one has gone before". His fictional productions treated only a motley collection of profound moral questions pertaining to human behavior at any time, any place. But despite the limits of its lineage, "Star Trek" showed us more truly the esoteric essence, the real meaning, of space exploration than did government statements on the commercialization of space. The essence of the US American space program, its heart and soul probably comes from "Star Trek". The starship enterprise brought also "Holodeck" which is a familiar vocabulary to the virtual reality pioneers. David Zeltzer from MIT Media Lab (USA) made a remark: "True virtual reality may not be attainable with any technology we create, Holodeck may forever be a fiction. Nonetheless, virtual reality serves as the Holy Grail of research" and furthermore increases the tension between unmanned and manned Space Research (Hartmann, 2011).

\section{The Supplement related to this article is available online at doi:10.5194/ars-12-237-2014-supplement.}

Edited by: M. Förster

Reviewed by: two anonymous referees

\section{References}

Bauer, S. J.: Solar System: Planets, Atmospheres and Life, in: Series Classics of World Science, edited by: Moskaliuk, Stepan S., 7, TIMPANI KYIV, 2003

Bauer, S. J.: Zwischen Venus\&Mars, Erinnerungen eines Weltraumforschers auf zwei Kontinenten, der Wolf Verlag, 2005.
Davies, K., Degenhardt, W., Hartmann, G. K., and Leitinger, R.: Comparison of total electron content measurements made with the ATS-6 Radio Beacon over the U.S. and Europe, J.A.T.P., 42, 411-416, 1980.

Dieminger, W., Hartmann, G. K., Leitinger, R. (Eds.): The Upper Atmosphere; Data Analysis and Interpretation, Springer Verlag, Berlin, Heidelberg, New York, 1996.

Hartmann, G. K., Ebel, A., Leitinger, R., Schmidt, G., and Schödel, J. P.: Gemeinsame Auswertung von Satellitensignalen zur Ermittlung des Elektroneninhalts der Ionosphäre für zwei Beobachtungsstationen, Kleinheubacher Berichte, 13, 29-36, 1969.

Hartmann, G. K. Degenhardt, W., and Leitinger, R.: Comparative study of ATS-6 data from Lindau/Harz and from Graz/Austria in: The geophysical use of satellite beacon observations, COSPAR/URSI-Symposium, Boston University, p. 219, June, 1976.

Hartmann, G. K.: Time series data between certainty and uncertainty, Prof. Dr. Karl Rawer dedicated for his 70th birthday, MPAE-L-66-93-14, 1983.

Hartmann, G. K.: Die Geschichte der Ionosphäre als globales Kommunikationsmedium, Beilage zu Kleinheubacher Berichte, Hrsg. FTZ Darmstadt, 31, 1988.

Hartmann, G. K., Noelle A., Richards, M. L., and Leitinger, R.: DUST-2 CD*: Improved Access to Information about the Earth Atmosphere, 2000a.

Hartmann, G. K., Noelle, A., Richards, M. L., and Leitinger, R. DUST-2: Towards a more efficient (interactive) documentation and validation of scientific information demonstrated with ozone, water vapor and other selected data of the Earth's atmosphere, Phys. Chem. A, 25, 607-612, 2000b.

Hartmann, G. K.: "Between unmanned and manned space research" Dr. Siegfried J. Bauer for his 80th birthday, Hist. Geo Space. Sci., 2, 81-82, doi:10.5194/hgss-2-81-2011, 2011.

Leitinger, R.: Interinstitutionelle Zusammenarbeit bei der Beobachtung des Satelliten Explorer 22 in Lindau, Köln, Graz, In: Festschrift zum 25 jährigen Bestehen (1945-1971) des Instituts für Ionosphärenphysik in Lindau am Harz, 207-208, 1971.

Leitinger, R., Putz, E., Hartmann, G. K., Degenhardt, W., Hedberg, A., and Ranta, A.: Total electron content in the Polar region. Sounding rocket program aeronomy; Project 7: Energy Budget compaign (EBC) 1980. Experiment summary, edited by: Offermann, D. and Thrane, E. V., 81-94, 1981.

Rawer, K.: The Ionosphere, its significance for geophysics and radio communications, F. Ungar Pub. Co., 1957.

Rawer, K.: Meine Kinder umkreisen die Erde. Bericht eines Satellitenforschers, Herderbücherei, 1226, 1986. 